Agr. Biol. Chem., 38 (5), 1045 1048, 1974

\title{
Antifeeding Active Substances for Insect in Plant
}

\author{
Shigeki Hosozawa, Natsuki Kato, Katsura Munakata \\ and Yuh-Lin CHEN* \\ Department of Agricultural Chemistry, Nagoya University, Nagoya, Japan \\ *Department of Agricultural Chemistry, National Taiwan University, Taipei, Republic of China
}

Received December 14, 1973

\begin{abstract}
The survey of the presence of chemical resistant factors in plants against the larvae of Spodoptera litura $\mathrm{F}$. was examined. In addition, the antifeeding diterpenes were surveied from thirteen species of plants that belong to Verbenaceae family. Finally isolated thirteen antifeedants and one derivative were examined the antifeeding activity for the larvae by the leaf disk method.
\end{abstract}

In the investigations of host plant selection of phytophagous insects, three aspects of particular interest for host specificity studies on weed insect had been proposed: host plant feeding, host plant acceptance for feeding and oviposition, host plant suitability for development and reproduction..$^{12 \sim \theta)}$ And also, it was suggested that the host plant acceptance for feeding in polyphagous species was governed by the botanical distribution of feeding stimullants and inhibitors. ${ }^{\text {1a) }}$ Recently many reports have dealt with the distribution and nature of chemical substances having the antifeeding activity for insect in plants. ${ }^{2 a \sim f)}$

The authors examined the survey of the presence of chemical resistant factors in various plants against the third instar of larvae of tobacco cut worm, Spodoptera litura $\mathrm{F}^{2 \mathrm{e} . \mathrm{d}, \mathrm{f})}$ This report consisted the isolation of thirteen antifeeding substances from five plants and the comparison of antifeeding activities of these compounds.

\section{MATERIALS AND METHODS}

Plants. Twenty three species of plants belonging to thirteen families were collected on Mt. Sanage, Aichi Prefecture, in Japan, Table I. Thirteen species of test plants that belong to Verbenaceae family were collected in Taiwan, Table II.

Preparation of sample solution for bioassay. The air-dried ground plant was refluxed wiph benzene for thirty minutes, and then the filtered benzene ex- tracts were concentrated under reduced pressure to give the crude gum. The crude gum was dissolved in acetone for the sample solution of freeding test in 10, $5,2.5$, and $1 \%$ concentrations, respectively.

Bioassay. The feeding test was carried out by the leaf disk method which was described in the previous paper. ${ }^{31}$ After $2 \mathrm{hr}$ for feeding test, each sample and control disks were removed from the polyethylene cup, and the remaining areas were measured and compared with each other.

\section{RESULTS AND DISCUSSION}

The results of the antifeeding activities for the benzene extracts from the test plants were shown in Table I. The benzene extracts of four plants, Caryopteris divaricata Maxim. (leaf and stem), Callicarpa japonica Thunb. (leaf), Boenninghausenia albiflora Reichb. (whole plant), and Ficus carica L. (leaf), showed the strong antifeeding activity at $1 \%$ concentration for the feeding test. Therefore, the presence of some antifeeding substances was expected in these plants.

\section{Antifeedants from B. albiflora Reichb}

The benzene extract of air-dried ground whole plant was chromatographed over alumina (Brockmann grade II) by elution with $\mathrm{MeOH}$-benzene gradient solvent system. The entomological test was used as a monitor for the fractionation. The antifeeding active fraction ( $1.5 \% \mathrm{MeOH}$-benzene) was chromatographed over silicagel by elution with 
Table I. Antifeeding Activity of Benzene Extract of Plant

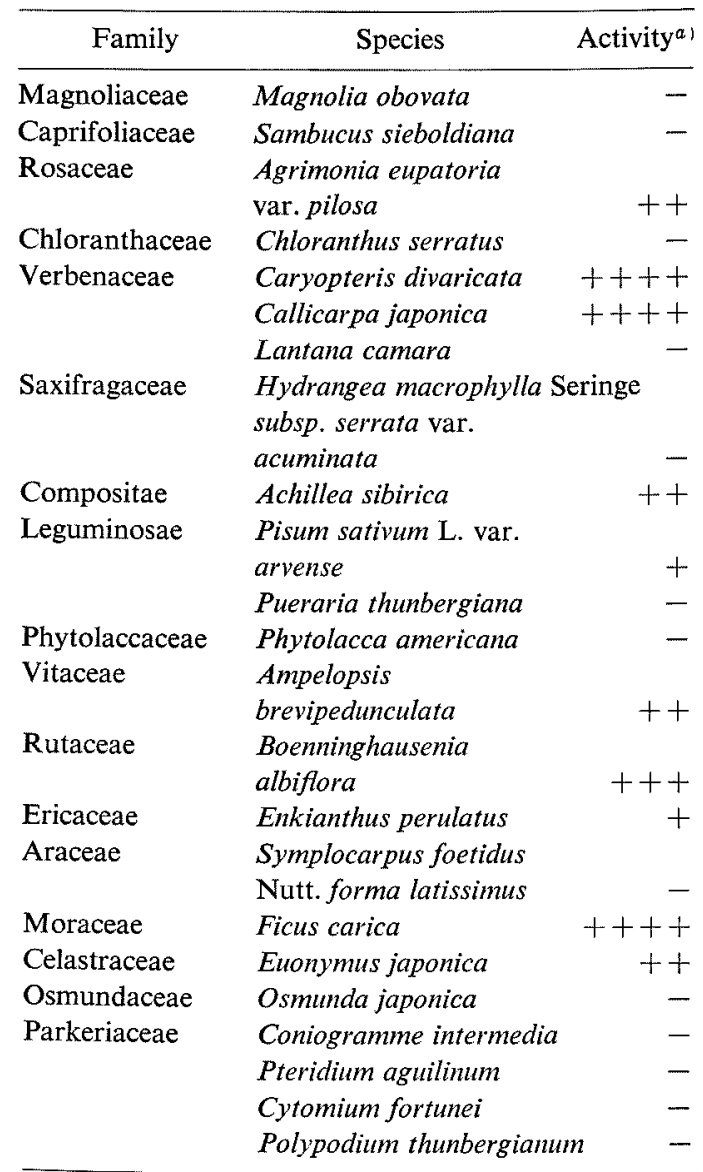

a) $t+++,+++,++$, and + show $80 \sim 100 \%$ antifeeding activity at $1,2.5,5$, and $10 \%$ concentrations, respectively. - shows no effect at $10 \%$ concentration.

EtOAc- $n$-hexane $(1: 1)$ and rechromatographed on silicagel eluted by $2 \% \mathrm{EtOH}-$ $\mathrm{CHCl}_{3}$ to yield two crystalline compounds, 1 and 2 , which were recrystallized from light petroleum to give $\mathrm{mp} 188 \sim 189^{\circ} \mathrm{C}$ and $127 \sim$ $129^{\circ} \mathrm{C}$, respectively. The each compounds of $\mathbf{1}$ and $\mathbf{2}$ was identified as bergaptene and xanthyletine, respectively, by the comparison with the reported values of spectroscopic data and $\mathrm{mp}$.

\section{Antifeedant from C. japonica Thunb}

The benzene extract of air-dried ground leaves was separated on alumina (Brockmann grade II) and silicagel by elution with same solvent system as using in B. albiflora. The strong antifeeding activity was observed in less polar fraction $(0.5 \% \mathrm{MeOH}-$ benzene eluate of alumina chromatography). In spite of the purification of active fraction (100\% antifeeding activity at $1000 \mathrm{ppm}$ ) using many isolation technique, strong antifeedant has not been obtained. However, the weak antifeedant 3 in the high content ( $0.2 \%$ yield on dried basis) was isolated from the active fractions, and identified as phytol by comparison with an authentic sample using spectroscopic data and GLC.

\section{Antifeedants from $C$. divaricata Maxim}

In our earlier works, it had been pointed out that the active substances in $C$. divaricata were unstable in the extraction with benzene under reflux condition rather than with ether, and very sensitive to acidic and basic conditions. Therefore, air-dried ground leaves and stems were extracted with ether at room temperature. Recently we reported the isolation and antifeeding activities of six diterpenes, 4 9.4) Then, in further scrutiny of the minor antifeeding diterpene components in this plant, we had isolated two new diterpenes, caryoptinol 10 and dihydrocaryoptinol 11, which were recrystallized from EtOAc-ether-light petroleum to give $\mathrm{mp} 219 \sim 220^{\circ} \mathrm{C}$ and $204 \sim 205^{\circ} \mathrm{C}$, respectively. ${ }^{5)}$ Above eight antifeeding diterpenes had the clerodane skeleton as a common structure, and showed a bitter taste.

\section{Survey of antifeeding diterpenes from Verbena- ceae plants}

Recently $\mathrm{N}$. Kato et al. ${ }^{6)}$ isolated the two antifeeding diterpenes, clerodendrin $\mathrm{A}$ and $\mathrm{B}$, having the same skeleton as in clerodin from Clerodendron tricotomum Thunb. that belong to Verbenaceae family.

Air-dried test plants were extracted with ether at room temperature. The antifeeding activity of each ether extracts was examined by the leaf disk method. These results were shown in Table II. The ether extracts of leaves of Clerodendron fragrans, $C$. calamitosum, and 
Table II. Antifeeding Activity of Ether Extract of Verbenaceae Plant

\begin{tabular}{|c|c|c|}
\hline Species & & $\overline{\text { Activity }{ }^{a 1}}$ \\
\hline Clerodendron fragrans & $\begin{array}{l}\text { (leaf) } \\
\text { (stem) }\end{array}$ & $\begin{array}{r}+++ \\
+\end{array}$ \\
\hline Clerodendron inerme & (stem) & + \\
\hline Clerodendron paniculatum & $\begin{array}{l}\text { (leaf) } \\
\text { (stem) }\end{array}$ & $\begin{array}{l}+ \\
+\end{array}$ \\
\hline Clerodendron calamitosum & $\begin{array}{l}\text { (leaf) } \\
\text { (stem) }\end{array}$ & $\begin{array}{r}++++ \\
+++\end{array}$ \\
\hline Clerodendron crytophyllum & $\begin{array}{l}\text { (leaf) } \\
\text { (stem) }\end{array}$ & $\begin{array}{r}+++ \\
+\end{array}$ \\
\hline $\begin{array}{l}\text { Clerodendron paniculatum } \\
\text { var. albiflora }\end{array}$ & (stem) & - \\
\hline Callicarpa formosana & $\begin{array}{l}\text { (leaf) } \\
\text { (stem) }\end{array}$ & $\begin{array}{l}+ \\
+\end{array}$ \\
\hline Duranta repens & $\begin{array}{l}\text { (leaf) } \\
\text { (stem) }\end{array}$ & - \\
\hline Lippia nodiflora & (whole plant) & - \\
\hline Premna integrifolia & $\begin{array}{l}\text { (leaf) } \\
\text { (stem) }\end{array}$ & - \\
\hline Vitex negundo & (stem) & - \\
\hline Vitex trifolia & (seed) & +++ \\
\hline Verbena officinalis & (whole plant) & - \\
\hline
\end{tabular}

C. crytophyllum exhibited the $100 \%$ antifeeding activity at $1 \%$ concentration. Consequently, the presence of one or more antifeeding substances was to be expected of these plants.

\section{Antifeedants from C.calamitosum and $C$. crytophyllum}

The ether extract of C.calamitosum was chromatographed over neutralized alumina (Brockmann grade V) by elution with etherbenzene gradient solvent system. The new antifeeding diterpene compound, 3-epicaryoptin 12, were obtained as colorless prisms, mp $171 \sim 172^{\circ} \mathrm{C}(0.01 \%$ yield on dried basis $)$, by the chromatographic purification on silicagel and recrystallization from ether-light petroleum. $^{7)}$

The ether extract of C. crytophyllum was separated on alumina column chromatography by elution with ether-benzene. The etherbenzene $(1: 5)$ fraction was chromatographed over alumina by elution with EtOAc-nhexane $(1: 1)$. The antifeeding substance 13 was obtained as crystals after the recrystal-
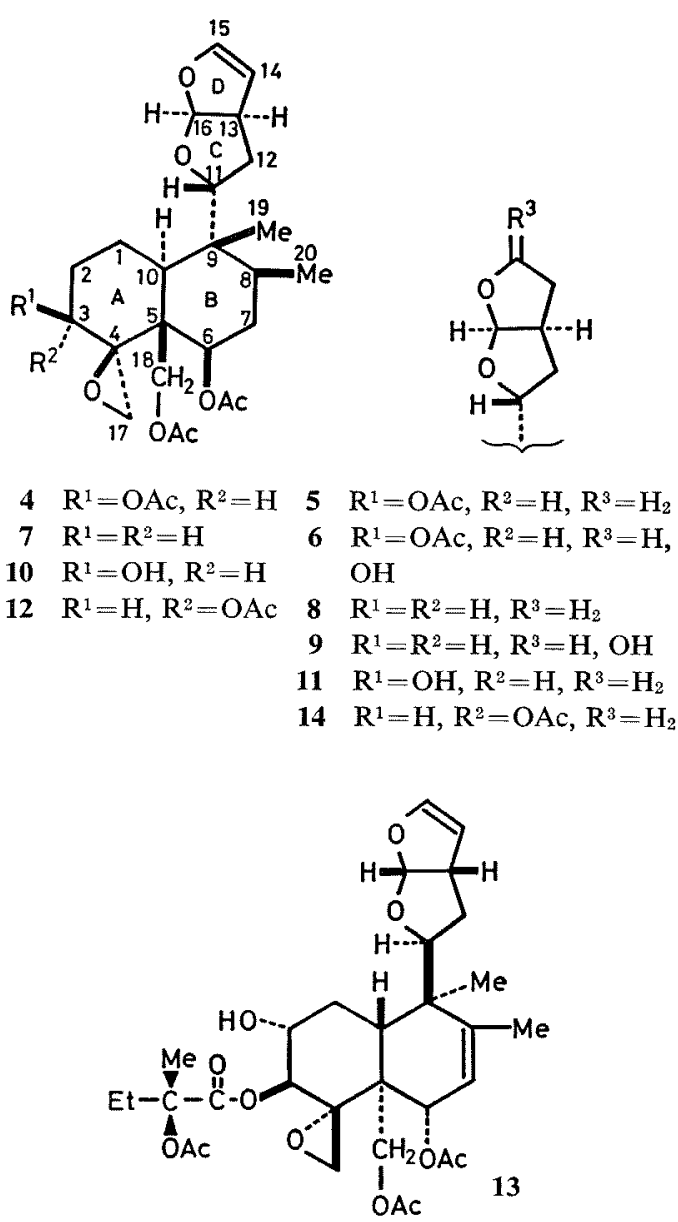

FIG. 1.

lization from EtOAc-ether-light petroleum mixed solvent in yield $0.002 \%$ on a dried basis. 13 was identified as clerodendrin-A by comparison with an authentic sample using spectroscopic data, mp and specific rotation.

It is interesting that the compounds containing the clerodane skeleton are found both in Clerodendron and Caryopteris species. And also, it is interesting in view of biogenesis that caryoptin is not found but 3-epicaryoptin is observed in C. calamitosum.

\section{Activity of natural occuring antifeedant}

Finally obtained thirteen antifeeding substances and one derivative were examined the antifeeding activities against the larvae of 
Table III. Activity of Natural OCCURRING ANTIFEEDANT

\begin{tabular}{|c|c|c|}
\hline & Compound & $\operatorname{ppm}^{a \prime}$ \\
\hline $\mathbf{1}$ & Bergaptene & 500 \\
\hline 2 & Xanthyletine & 2500 \\
\hline 3 & Phytol & 5000 \\
\hline 4 & Caryoptin & 200 \\
\hline 5 & Dihydrocaryoptin & 80 \\
\hline 6 & Caryoptin hemiacetal & 200 \\
\hline 7 & Clerodin & 50 \\
\hline 8 & Dihydroclerodin-I & 50 \\
\hline 9 & Clerodin hemiacetal & 50 \\
\hline 10 & Caryoptinol & 200 \\
\hline 11 & Dihydrocaryoptinol & 100 \\
\hline 12 & 3-Epicaryoptin & 200 \\
\hline 13 & Clerodendrin-A & 200 \\
\hline 14 & 3-Epidihydrocaryoptin ${ }^{b}$ & 100 \\
\hline
\end{tabular}

S. litura at the different concentrations. The antifeeding activity was embodied in the concentration of sample solution which exhibited the $100 \%$ antifeeding activity within the defined time ( $2 \mathrm{hr})$, Table III.

10,12 , and 13 showed the same $100 \%$ antifeeding activities at $200 \mathrm{ppm}$ concentration as that of 4 , which showed the weak antifeeding activity than clerodin. 11 and 14 showed the same $100 \%$ antifeeding activity at $100 \mathrm{ppm}$ concentration. From these facts, the derivatives have the saturated D ring is more active for the larvae than those of the unsaturated $\mathrm{D}$ ring. Previously we have suggested that the difference of the activities between clerodin and caryoptin series may be attributed to the presence of $3 \beta$-acetoxyl group on A ring. ${ }^{3 \prime}$ However, the difference of the activities accompanying the change of the configuration and functional groups of $\mathrm{C}-3$ position on $\mathrm{A}$ ring is not definitely observed in this feeding test.

In addition, the feeding test was allowed to continue for $6 \mathrm{hr}$ and more at the concentration showing the $100 \%$ antifeeding activity. The test leaves treated with the antifeeding diterpenes, $4 \sim 14$, were not bitten after $24 \mathrm{hr}$ and more, and then the larvae eventualy starved to death. ${ }^{2 f, 3)}$ Therefore, the term of "absolute

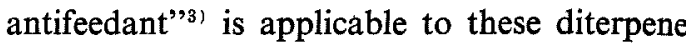
compounds. And also the term of "relative antifeedant"3) is used to 1,2 , and 3 which retarded the feeding of larvae only within the defined time. These three relative antifeedants did not exhibit the antifeeding activity after $6 \mathrm{hr}$.

If insect antifeeding active substances are classified as the concepts of "relative antifeedant" or "absolute antifeedant," it will shed light on novel and specific actions of the substances for insects.

\section{REFERENCES}

1) a. A. J. Thorsteinson, Ann. Rev. Entomol., 5, 193 (1960).

b. S. D. Beck, ibid., 10, 207 (1965).

c. J.S. Kennedy, Ann. Appl. Biol., 56, 317 (1965).

d. H. L. House, Can. Entomol., 98, 1121 (1966).

e. H. Zwölfer and P. Harris, Ann. Rev. Entomol., 16, 159 (1971).

2) a. H. Buhr, R. Toball, and K. Schreiber, Ent. Exp. Appl., 1, 209 (1958).

b. B. Stürckow and I. Löw, ibid., 4, 133 (1961).

c. K. Wada and K. Munakata, J. Agr. Food Chem., 16, 471 (1968).

d. K. Wada, K. Matsui, Y. Enomoto, O. Ogiso and K. Munakata, Agr. Biol. Chem., 34, 941 (1970).

e. J. H. Butterworth and E. D. Morgan, J. Insect Physiol., 17, 969 (1971).

f. N. Kato, M. Takahashi, M. Shibayama and K. Munakata, Agr. Biol. Chem., 36, 2579 (1972).

3) S. Hosozawa, N. Kato and K. Munakata, Agr. Biol. Chem., 38, 823 (1974).

4) S. Hosozawa, N. Kato and K. Munakata, Phytochemistry, 12, 1833 (1973).

5) S. Hosozawa, N. Kato and K. Munakata, ibid., 13 (1974).

6) a. N. Kato, S. Shibayama and K. Munakata, Chem. Commun., 1971, 1632; J.C.S. Perkin I. 1973, 712.

b. N. Kato, K. Munakata and C. Katayama, J.C.S. Perkin II, 1973, 69.

7) S. Hosozawa, N. Kato and K. Munakata, Phytochemistry, 13, 308 (1974). 